\title{
Yane Sandanski as a political leader in Macedonia in the era of the Young Turks
}

\section{Mehmet Hacısalihoğlu}

\section{OpenEdition}

1 Journals

Electronic version

URL: https://journals.openedition.org/ceb/1192

DOI: $10.4000 /$ ceb. 1192

ISSN: 2261-4184

Publisher

INALCO

\section{Printed version}

Date of publication: 9 January 2012

ISSN: 0290-7402

\section{Electronic reference}

Mehmet Hacısalihoğlu, "Yane Sandanski as a political leader in Macedonia in the era of the Young

Turks", Cahiers balkaniques [Online], 40 | 2012, Online since 21 May 2012, connection on 06 July 2021 URL: http://journals.openedition.org/ceb/1192 ; DOI: https://doi.org/10.4000/ceb.1192

This text was automatically generated on 6 July 2021.

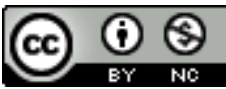

Cahiers balkaniques est mis à disposition selon les termes de la Licence Creative Commons Attribution - Pas d'Utilisation Commerciale 4.0 International. 


\title{
Yane Sandanski as a political leader in Macedonia in the era of the Young Turks
}

\author{
Mehmet Hacısalihoğlu
}

1 Like all nation-states, the Balkan states have had their historical heroes. These heroes were mostly armed men fighting against Ottoman rule -- such as Vasil Levski, Gotse Delčev, and Pavlos Melas -- or poets and thinkers advocating the fight against the "Turkish yoke" - for example, Regas Velestinlis and Hristo Botev ${ }^{1}$. One of their common characteristics is that they were all killed by the Ottoman authorities, either shot dead in combat or hanged by the Ottoman court. By the time of their death, they were young and generally had not had the opportunity to act as politicians. Consequently, they could be portrayed as honest fighters for independence over the course of nation-building process in the Balkans.

2 Yane Sandanski, the subject of this paper, was a famous leader of the Inner Macedonian Revolutionary Organization (IMRO). He was considered a hero already during his lifetime. After the 1908 Revolution, he ceased the illegal armed movement and began to act as a politician in Macedonia ${ }^{2}$. During the Balkan Wars, he returned to the illegal armed movement. Like many of his friends, he was assassinated by the Bulgarian nationalists in $1915^{3}$.

3 There have been many studies on Sandanski written in Bulgaria and the Macedonian Republic, dealing with his activities in Macedonia particularly between 1902 and $1908^{4}$. In comparison, his role and activities during the years of the Young Turk government (1908-1912) are less researched in both of these countries ${ }^{5}$. In the national historiographies of the Balkan states today, Sandanski has a very controversial image. Particularly in Bulgaria, he is portrayed as a betrayer of the Bulgarians, as a friend and collaborator of the Turks (seen as Bulgarian enemies) and as a robber who was only motivated by money ${ }^{6}$. The reason for Sandanski's negative image among nationalist historians in Bulgaria is his active role as a local politician in Macedonia during the years of the Young Turks rule, between 1908 and 1912. On the contrary, in the Republic 
of Macedonia, the image of Sandanski is much more positive. He is portrayed as a fighter against the "Bulgarian aspirations in Macedonia" and against the "Turkish yoke". He is, however, not the first and most important hero of the Macedonian national movement. The national Macedonian hero in the historiography of Skopje is Gotse Delčev ${ }^{8}$. Delčev was the organizer of the armed (četa) movement in Macedonia. He was killed very early on while fighting against the Ottoman gendarmes in 1902. The Bulgarian historiography also characterizes Delčev as one of the most important leaders of the Macedonian struggle 9 . According to Bulgarian historiography, IMRO was a Bulgarian organization and Delčev a Bulgarian hero in Macedonia.

4 The controversies in the historiography make the evaluation of Sandanski and his role in the Macedonian Question very difficult. Carefully examining the primary sources, I tried to find an explanation for the case of Sandanski in the context of my doctoral research, and this turned out to be one of the most difficult questions. In this study, I will discuss the role of Sandanski predominantly as a political leader. Was he an important political leader? What was his attitude towards the Young Turks government? What was his relationship with other political groups and organizations? These are the main questions to be discussed in this study.

\section{Sandanski and the Young Turk Revolution}

From 1903 on, Sandanski and his group, the left-wing of the IMRO, dominated the eastern part of Macedonia-that is, the Serres and Strumitsa districts extending to the Bulgarian border. The gap between the two wings, namely the left and right-wings of the IMRO, widened increasingly after the Ilinden-Uprising 1903 and even turned into a bloody struggle. The right wing of the IMRO was more active in the western parts of Macedonia, around Skopje and Bitola.

6 The reason for this conflict was that both factions had different political goals and motivations regarding the future of Macedonia and Adrianople. The first group aimed to unify Macedonia with Bulgaria, while the second advocated the formation of a Balkan federation ${ }^{10}$ including Macedonia as an equivalent member. The right-wing faction of the organization was supported by the Bulgarian government and made attempts to take Sandanski's region under control. This provoked a battle between the two groups. During this conflict, in November 1907, the leaders of the right-wing, Boris Sarafov and Ivan Garvanov, were killed in Sofia by Panitsa, a close friend of Sandanski. This marks the high point of the conflict among these two factions. From this date on, the struggle against the Ottoman administration and the Greek and Serbian organizations held only secondary importance.

1. Yane Sandanski, 1910 


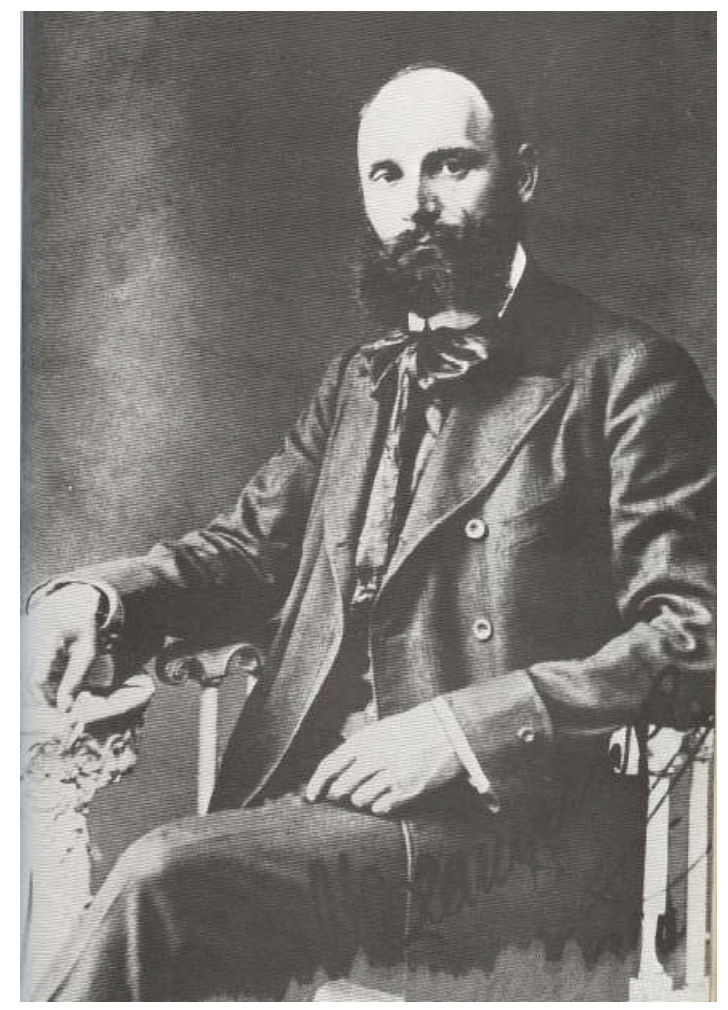

(Source : Macdermott, Za Svoboda)

7 The struggle of Sandanski and his group was primarily directed against the Bulgarian nationalists and official Bulgarian authorities. This conflict weakened the position of the IMRO in Macedonia against the Greek and Serbian enemies. Despite his success against the right wing, Sandanski's position was not favorable at the beginning of 1908, and as consequence of the reforms within the Ottoman gendarmerie, an armed movement in Macedonia became much more difficult to organize and maintain than it had been at the beginning of the century ${ }^{11}$.

8 Under pressure, Sandanski decided to contact the Young Turks who were trying to gain the support of the Macedonian committees. The leftist journalists and intellectuals Dimo Hadžidimov and Pavel Deliradev were supporting Sandanski in his decision to contact the Young Turks' committee. Since January 1908, the social democrats in Adrianople had been supporting Sandanski against the right-wing and began to propagate the idea of a "constitutional Turkey" in their newspaper "Odrinski Glas"12. At a congress in the spring of 1908, Sandanski and his group decided to negotiate with the Committee of Union and Progress (CUP); however, before he met the director of the CUP of Nevrokop ${ }^{13}$, the Young Turks Revolution broke out ${ }^{14}$.

On the first day of hürriyet, the proclamation of "freedom" in Macedonia, Sandanski and the Young Turks leader of Nevrokop met in Gaytaninovo, a village in the district of Nevrokop. Together they celebrated the success of the revolution. Then Sandanski, accompanied by the local leaders of the Young Turks, travelled to Salonica, the center of the Young Turks' Committee, passing through the cities Serres and Drama. He was received by the hero of the Revolution, Enver Bey, and a large number of curious people welcomed Sandanski with great enthusiasm. Among the Ottoman public he was also named "King of the Mountains" and "Sandan Pasha" ${ }^{15}$. Sandanski was celebrated in 
Salonica like a hero of the revolution. The Ottoman-Turkish newspaper Yeni Asir reported on Sandanski on 16, 17 and 18 July 1908 as follows:

"The head of the leaders of the Bulgarian çetes, famous Sandanski, will come to Salonica within a few days. Sandanski is a captain famous for his patriotism and conscience. It is known that the Bulgarian Committee which had caused the awakening of the Macedonian Question was later split into two fractions, named Centralists and Vrhovists. The first of these fractions adopted the idea of Macedonia for the Macedonians and opposed the aim of unifying Macedonia with Bulgaria; it began to follow the aim of reforming the fatherland, and gaining freedom and equality. He has been living in the mountains for ten years and led this party with great success. He succeeded in killing Sarafov and many other famous leaders working to unify [Macedonia] with Bulgaria, against whom the weak [Ottoman] government was powerless.There is no doubt that Sandanski will be greeted with great acclamations, as he deserves it" ${ }^{\prime 16}$.

The following day, the same newspaper reported that Sandanski, Panitsa, and their companions-called "heroes" (kahramanlar)-had been celebrated in Drama and Serres, and that they had arrived around 3 o'clock in the early morning in Salonica, where they were greeted by a "committee of high-ranking people." Further, the newspaper reported: "Although the weather was bad and it was raining, they were celebrated by thousands of people on the streets"17 Sandanski gave speeches in Salonica and was celebrated with great enthusiasm. According to Yeni Asir, "Sandanski Efendi is perfectly educated, deserves to be a deputy; he is a perfect person and a brave fighter (fedai)." According to the newspaper, the public speeches of Sandanski "fascinated the public." The same newspaper quoted Sandanski's answer to the question: "You have been used to living in the mountains for years. What kind of job will you do now?" He answered: "As I worked in the mountains, I will continue to work for the sacred fatherland with heart and soul in any kind of duty for which the fatherland employs me and any kind of task the fatherland expects from me"18.

11 It was very important for the Young Turks to show that the head of the armed committees was laying down arms and joining them. This was an important evidence of the fact that the CUP brought peace to Macedonia, which witnessed a bloodbath because of ethnic conflicts. Through his presence in Salonica and his speeches about brotherhood and the end of the national struggle, Sandanski contributed enormously to the stabilization of the new regime in Macedonia. He published a proclamation addressed to Muslims and non-Muslims alike and advocated support for the Young Turks. The leaflet, signed by Sandanski, stated the following:

\section{Manifesto to all Peoples of the Empire}

[...]

Turkish Citizens,

You form the large majority of the people [nation], but despite that you felt most of the evil acts of the common enemy too. In your "Turkish Empire" you were not less enslaved than your Christian citizens. Until now, our rulers deceived you about the fact that the Christians were your enemies. Now you have understood who your brothers and your enemies are. You went first to fight for freedom and equality. All peoples are together with you. Your call "The peoples are brothers, and they shall live like brothers" is warming the hearts of the Christian population and triggers the difficult question: In which way can freedom be achieved? So, the fight you started against tyranny shall live so that the entire people live.

Dear Christian Citizens,

You also were not any less deceived, and you believed that your troubles came from the tyranny of the entire Turkish people. This error has ceased to exist. The Turkish people had 
never any interest in enslaving you. Now, you gave a brotherly hand to each other, and only with this alliance will you achieve the freedom you have desired so much until now and for which you have made so many sacrifices. Strengthen this alliance [!] Let us also bury the national fights of self-destruction created by the tyranny, along with the tyranny itself [!] Co-nationals [Compatriots],

You, who brought so many valuable victims before the Altar of Freedom, can breathe with pleasure. Now you are not alone-and therefore your fight will be easier and full of hope. With the common effort of all peoples we will achieve our freedom. Do not believe in the criminal agitations that the official governments in Bulgaria could eventually lead against your common fight, together with the Turkish people and their intelligentsia in striving for freedom.

[...]

Salonica, 18 July 1908

SANDANSKI ${ }^{19}$

This manifesto constituted an important source of support for the new regime. Until the revolution, Sandanski had been an illegal "bandit"; now, all of a sudden he had become a legitimate political leader in the Ottoman Empire. The interesting point was that, in the manifesto, Sandanski warned the Bulgarian-Macedonians against the Bulgarian government. With this manifesto Sandanski openly declared that he supported the Young Turks and that he was suspicious of the aspirations of Bulgaria and other neighboring nation-states desiring the annexation of Macedonia. Sandanski and his friends, such as Pavel Deliradev, repeated these opinions about the Balkan states in different meetings and speeches in Salonica during the following days and weeks.

2."Manifesto to All People Groups in the Empire" signed by Sandanski, on July 18, 1908

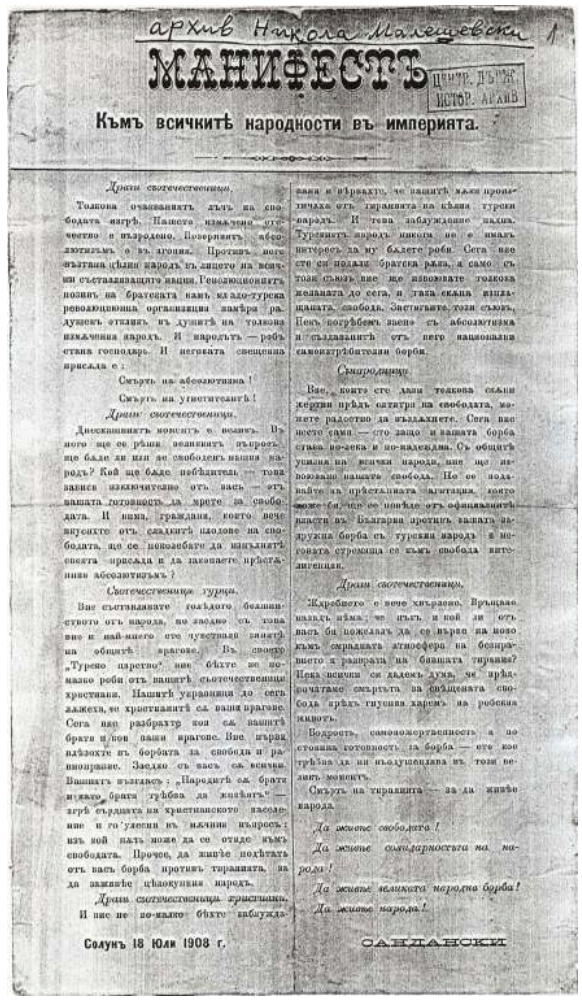

Signed by Sandanski, on July 18, 1908

Deliradev said the following: 
"I was present in official banquets in Bulgaria, in which everybody drinks on a San StefanoBulgaria with a King. An alliance we should make with Turks, but not with Bulgaria. From Bulgaria we can expect only evil, but never any benefit"20. with negotiations with the CUP. Gaining the support of a very famous Christian committee leader like Sandanski was very important for the CUP. This contributed to the legitimization of the change of power in the eyes of the European public. Being aware of this fact, the Young Turks adopted a very positive attitude towards Sandanski. But they were also interested in receiving support from other committees in the empire. Thus, they tried to bring the right and left wings of the IMRO together. By unifying both factions, they wanted to have only one Bulgarian/Macedonian organization with whom they had to negotiate. The unification attempts failed, and the rivalry among the two groups continued in the new period, in the form of mutual propaganda. Sandanski was sentenced to death and attacked by the members of the right wing. He survived two assassination attempts in Salonica on 24 September 1908 and 14 August $1909^{21}$.

Sandanski's attitude towards the new regime and the Young Turks can be interpreted as an attempt to maintain and strengthen his relative power and position in Macedonia. He was aware of the fact that maintaining his position depended on good relations with the CUP. Sandanski tried to assure the confidence of the Young Turks; this was not difficult for him, because his enemy-namely, the right wing-adopted a very reserved attitude towards the CUP. As already mentioned above, the Ottoman press portrayed Sandanski as a reformist leader advocating the territorial integrity of the empire, while the right wing was described as separatists.

During the negotiations, both Sandanski and the right wing demanded political decentralization in Macedonia. The right wing contacted the Bulgarian government and tried to save the privileges of the Bulgarian Exarchate. Sandanski, however, was against the religious character of education and demanded its secularization. This was the main difference in the claims of both wings of the IMRO.

The left wing of the IMRO prepared a political program and thereby began to act like a legitimate political party. The political program of Sandanski's group, called Sandanists, was published in French in the first number of the newly established newspaper of the left wing, Konstitutsionna Zarya (L'Aube Constitutionelle / Fecr-i Meşrutiyet), dated 8/21 August 1908. The main points-that is, their political demands and proposals-of the program were as follows:

1.La destruction de tout reste du régime absolu et l'introduction de la souveraineté populaire; la démocratie absolue dans l'Empire ottoman, dont la Macédoine et le vilayet d'Adrinople [sic] font une partie inséparable [...]

2.L'autonomie des provinces vis-à-vis de l'Empire, l'autonomie des départements vis-à-vis [les] provinces et l'autonomie des communautés vis-à-vis de départements dans la réglementation de leurs affaires intérieures et de leurs intérêts. [...] 
3.Le choix des membres des corps législatifs et administratifs, centraux et locaux (provinciaux, départementaux et communaux) se fera au suffrage universel, égal, direct, secret et proportionnel.

4.La liberté de conscience, de parole, de la presse, de réunion et des associations. [...]

5.La suppression de tous les privilèges de nationalité et de classe; l'égalité absolue de toutes les nationalités et de tous les groupes religieux. Le droit pour chaque nationalité de s'organiser librement et séparément.

6.L'instruction primaire générale, rendue obligatoire et gratuite. L'instruction sera donnée en langue maternelle. [...]

7.L'armée permanente sera changée eu une milice populaire armée. Le service militaire est obligatoire pour tous les citoyens capables et en âge de porter les armes. [...]

Exigences économiques

1.La suppression de tous les droits et de toutes les charges qui mettent la population dans un véritable état de servage.

2.Confiscation des terrains du Sultan et des vacoufs; l'État devra exproprier les fermiers de leurs grandes propriétés (tchiflik) et les partager entre les communautés et villages pauvres. 3.La loi doit protéger le travail agricole, industriel et journalier.

4.L'abolition de tous les impôts directs et indirects (en nature ou en argent) et leur échange en un impôt progressif sur les revenus et les héritages $[. . .]^{22}$

18 Among these points, particularly the demands regarding autonomous provincial government and the abolishment of the privileges of different national groups were particularly important. The first one was against the expectations of the Young Turks and the second against the demands of the Greek Patriarchate and the Bulgarian Exarchate.

19 Together with the political program, Sandanski's group published a declaration on 8/21 August 1908 in the same newspaper. The declaration was as follows:

L'Organisation Révolutionnaire Macédo-Adrinopolitaine, par l'absolutisme dominant et illimité du Sultan qui, faisait impossible toute apparition d'idée libre ou action sociale libre dans les limites de l'Empire était contrainte de lutter illégalement et les armes à la main poursuivre ses problèmes et idéales.

Puisque pour le moment sont introduits dans l'Empire les premières et plus élémentaires conditions d'une action légale, politique, la lutte de l'Organisation aussi parait dans des formes légales, sans avoir recours aux armes. Mais pour ne pas croire enfin que l'Organisation change tout à fait son caractère de force armée, par cet acte, elle déclare que, les armes ne sont pas déposées et, qu'elle est prête, à tout moment, les prendre à main et continuer la lutte en forme illégale.

Mais comme l'Organisation révolutionnaire a le désire de mettre fin, une fois pour toutes, aux luttes sanguinaires, citoyennes et politiques dans l'Empire ottoman, déclare qu'elle est prête à se réorganiser et transformer, d'une Organisation conspirative et guerrière qu'elle est, en une Organisation-pour l'action légale et politique. Mais comme garantie pour ces demandes, elle insiste que la nouvelle situation politique assure par une voie légale toutes les conditions pour libre apparition des lutes politiques et pour une Organisation des actes citoyennes et politiques, sans aucun obstacle.

Comme mesures qui peuvent garantir ses demandes exprimées plus haut l'Organisation Ma.Adrinopolitaine compte (cite) :

La convocation du Parlement général de l'Empire en se basant sur le vote et le droit d'élection général, égal, direct et secret, en même temps à ces conditions

[here follow the conditions in five points]

Le Parlement général de l'Empire doit sanctionner tout de suite l'amnistie politique générale et réviser la Constitution de 1876 dans l'esprit du programme de l'Organisation.

[Here follow further points regarding the local government and armament of the population]

L'Organisation M.-Adrinopolitaine déclare qu'elle est prête d'accepter tout secours ou d'aider les efforts de toute autre Organisation révolutionnaire dans l'Empire ottoman, sans tenir 
compte des diversités principales ou des haines historiques, à condition que leurs actions auront pour but à acquérir les susdites garanties, sans lesquelles est impossible de constituer un régime constitutionnel-démocratique qui, le seul est capable d'introduire l'ordre et la paix dans l'Empire et d'assurer aux nations qui le composent un progrès économique et de culture $^{23}$.

With this proclamation, the left wing of the IMRO under Sandanski officially declared the transformation of the IMRO into a legitimate political party.

\section{3. "Sandanski"}

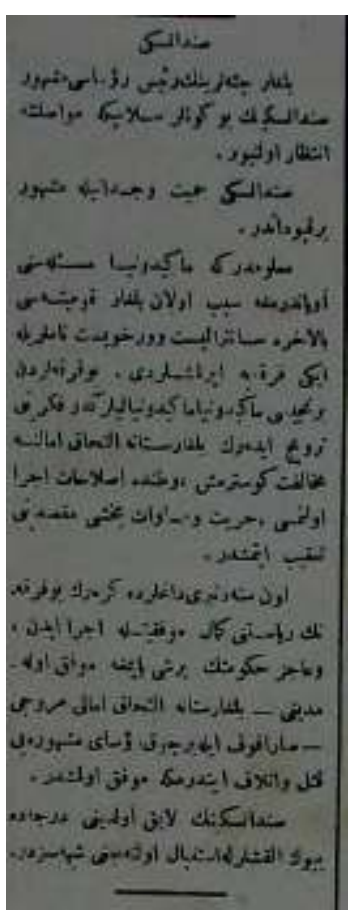

Yeni Asır, no 1304, 16 Temmuz 1324 / 29 Juillet 1908, p. 2

\section{4. "Sandanski"}




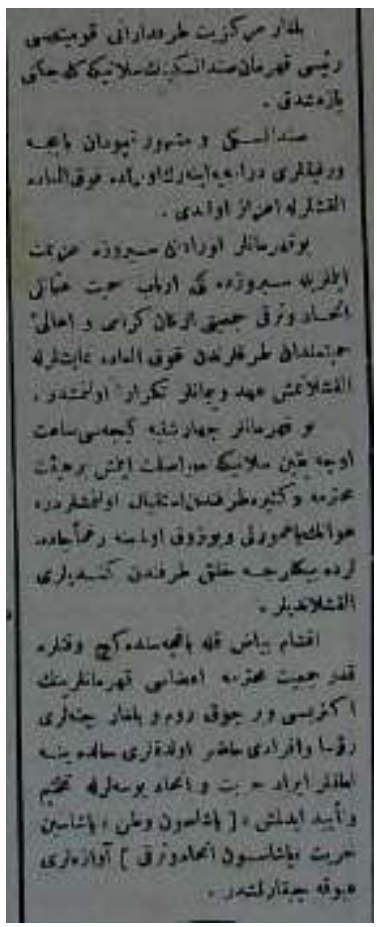

Yeni Asır, nº 1305, 17 Temmuz 1324 / 30 Juillet 1908, p. 2.

21 Like the Sandanists, other political groups in the empire sent their political programs and demands to the center of the CUP in Salonica. The CUP prepared a program in which they declared that it was a "compromise program" considering the demands of different political groups ${ }^{24}$. The "compromise program" of the CUP included several of the Sandanists' demands regarding agrarian reform and the like. But it was a centralist program, and the demands of all non-Turkish political groups in Macedonia for the decentralization of administration were rejected. A common program for the solution of the Macedonian Question could not be found throughout the negotiations in July and August $1908^{25}$.

5. "Sandanski" 


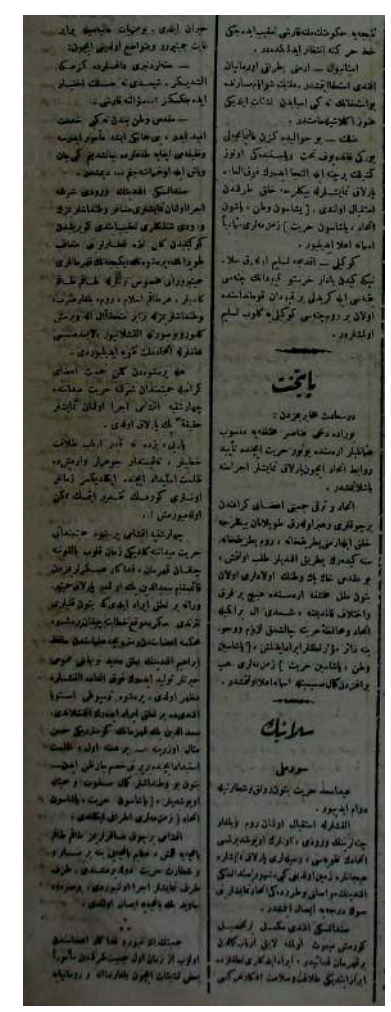

Yeni Asır, no 1306, 18 Temmuz 1324 / 31 Juillet 1908, p. 1

The next step was the general elections in October and November 1908. In the elections, the most important rival of Sandanski was the new Bulgarian Constitution Clubs established by the right wing in cooperation with the Exarchate and the Bulgarian government. In the area of his influence, Sandanski did not tolerate any propaganda attempts of the Bulgarian Constitution Clubs. The Bulgarian government accused the Young Turks of supporting Sandanski against the Constitution Clubs. For the CUP, however, it was important that all significant population groups were represented in the new Ottoman parliament. This would give evidence that, on one hand, no population group had the dominant majority in Macedonia; on the other hand, it would be easier to balance the interests of the different political groups in Macedonia and to manage them ${ }^{26}$.

In the end, two representatives of the Bulgarian Clubs (Todor Pavlof from Skopje, Pančo Dorev from Monastir) and two representatives of the left wing (Dimitar Vlahov from Salonica, Hristo Dalčev from Serres) were elected. In January 1909, the left wing of the IMRO established the Federal People's Party (Bulgarian Section). The new party began to publish the newspaper Narodna Volya (People's Will) on 17 January 1909, as its newspaper. ${ }^{27}$ Until the middle of 1909 , the relations between the leftist group and Sandanski were harmonious. When the counter-revolution (in Turkish known as 31 Mart Vakasl) started in Istanbul, Sandanski and his friends joined the forces of the CUP as volunteers and put down the rebellion in Istanbul. He and his men were celebrated as saviors of "freedom" in Istanbul and Salonica. He received gifts from the CUP, including a horse of the newly overthrown Sultan Abdulhamid and privileges such as the use of the thermal springs and forests of Melnik. ${ }^{28}$ With his help against the enemies of the CUP, he expressed once more his loyalty to the new regime and his alliance with the CUP. 


\section{Sandanski after the Abolishment of National Political Organizations}

The CUP soon began to take restrictive measures against national organizations and political parties in the empire. On 23 August 1909, the parliament accepted a law banning national political organizations and parties ${ }^{29}$. Political organizations with ethnic or national names had to change their names within two months. The Bulgarian Constitution Clubs under Toma Karayovov protested this law and decided to dissolve the organization.

\section{Sandanski in Četnik Uniform}

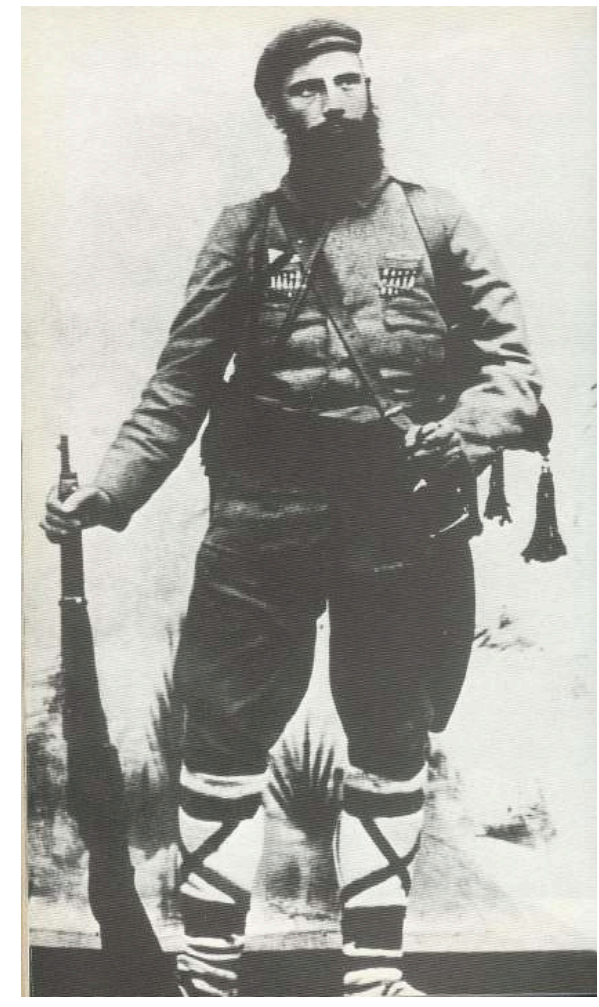

(Source: Macdermott, Za Svoboda)

The relations between the CUP and the Bulgarian-Macedonian members of the parliament began to deteriorate. These restrictive measures of the Ottoman government in the middle of 1909 also affected Sandanski's relations with the Federal People's Party and the leftist deputies in the Ottoman parliament. Sandanski resigned from the Federal People's Party. He was criticized by both the Constitution Clubs and the leftist deputies who pursued a more Bulgarian nationalist attitude in the parliament.

Through his good relations with the CUP, Sandanski played an important role in the appointment of local administrators and the affairs of school education. He acted as a provincial leader in the region of Serres, Drama, and Strumitsa, and as advisor to the 
CUP. At the beginning of 1910, however, a very close friend of him, Hristo Černopeev, who was the leader of the leftist group in Strumitsa, left politics and migrated to Sofia. There, he founded a new illegal organization, the Bulgarian National Macedonian Adrianople Revolutionary Organization, which was then called the new IMRO. Černopeev also invited Sandanski to join him; however, Sandanski did not respond to his call. The national Bulgarian press used this opportunity and launched a propaganda campaign against Sandanski. Sandanski was attacked and accused of betraying the Bulgarians in Macedonia, since he did not launch an illegal armed movement against the Ottoman government. Despite great pressure on Sandanski by many leftist activists and deputies, the Bulgarian press and his very close comrades (such as Černopeev), Sandanksi did not show any reaction to these critiques. He continued with his legitimate political activity ${ }^{30}$.

Armed movements reemerged in Macedonia in 1910, and also the Albanian revolts began to destabilize Ottoman rule in the region. This gave a reason to the Ottoman government under the CUP to begin a general disarmament operation among the region's population. Applying oppressive measures, the Ottoman government disarmed first the Albanians and then the Macedonians. The national Bulgarian groups resisted this measure, which provoked the Ottoman authorities to institute even more oppressive measures. Many members of the right-wing group took refuge in Bulgaria. The CUP also wanted to carry out the disarmament of the population in the region dominated by Sandanski. Sandanski, however, rejected this action, thereby causing tension between him and the CUP. In the process of negotiations, Sandanski ensured the CUP that in his region he was responsible for all illegal actions and that it was not necessary to disarm the population. In the end, the CUP accepted Sandanski's proposition and halted the disarmament of the Christian population in the area of Serres and Drama ${ }^{31}$.

\section{Sandanski during the Rise of Opposition against the CUP and the Balkan Wars}

In 1911, opposition against the CUP became more powerful. Parallel to this development, opposition of the Bulgarian government, the national Bulgarian circles, and the Bulgarian press against Sandanski also increased. The Bulgarian-Macedonian members of parliament, Hristo Dalčev and Dimitar Vlahov, who had been elected to parliament with the support of Sandanski and the left wing of the IMRO, began to defend the Bulgarian national cause in Macedonia and came into conflict with Sandanski. Even the socialist groups in Bulgaria criticized Sandanski as a collaborator of the Turks ${ }^{32}$. The newly established IMRO, which was a purely Bulgarian nationalist committee, began its activities in Macedonia in 1910, with the aim of destabilizing the Ottoman government and preparing Macedonia for a war in which Bulgaria was expected to lead with the aim to annex Macedonia. This new committee preferred to execute bomb attacks in cities. Interestingly, however, Sandanski did not change his policy and maintained his alliance with the CUP. As he had done before, he rejected any interference by the Bulgarian nationalists in the area of his influence. The last evidence of Sandanski's collaboration with the CUP was the general elections in February / March 1912. Thanks to the alliance with the CUP, Sandanski's candidates, Stoyu Hadžiev and Aleksandăr Buynov (Serres), were elected to the Ottoman parliament. The 
other three Bulgarian representatives elected to parliament were also in alliance with the CUP ${ }^{33}$.

The new parliament, however, was dissolved as a consequence of the emergence of an oppositional group in the Ottoman military. The CUP government was forced to resign in the middle of 1912. On the verge of the Balkan Wars, Sandanski decided to launch once more an armed movement against Ottoman rule. This decision was influenced by two important factors: first, Sandanski could foresee that the Bulgarian army, supported by the other Balkan states, would occupy the area dominated by him. In that case, it would be more reasonable to be in alliance with Bulgaria. Second, the CUP was no longer in the Ottoman government; on the contrary, committee members were mistreated and punished by the new government that was formed after the fall of the CUP government. Consequently, Sandanski was left all alone. By joining the Balkan alliance, he probably expected that Macedonia would gain some sort of autonomy, or that the new government would recognize the rule of Sandanski in the area of his influence ${ }^{34}$.

During the First Balkan War, the area that Sandanski dominated was occupied by Bulgarian forces. Sandanski helped the occupying armies with his guerillas. The Bulgarian Macedonian bands destructed the infrastructure of the region in order to help the armies of the Balkan states; they burnt Muslim villages, massacred Muslim population. According to the reports from the district of Kukuş, not far from Salonica, for example, a chief of the Bulgarian bands, Dončev, "burnt three Turkish villages in one day, Raianovo, Planitsa and Kukurtovo - 345 houses in all. He shut up the men in the mosques and burnt them alive; the women were shut up in barns and ill used; children were actually flung against the walls and killed" ${ }^{35}$. Within the region of Sandanski, the armed bands treated the Muslims in the same way. The Muslim men of the village Petrovo were shut up in a coffeehouse and the women in a building, and they were all burnt. Only the children were left alive. According to M. Makdermot, Sandanski did not know about this incident. He usually tried to prevent such massacres on the Muslims. When he learned about this massacre in Petrovo, he gave the children of killed Muslims to the Bulgarian villagers ${ }^{36}$.

31 After the capture of the region, the Bulgarian government established a central administration in the region and did not tolerate any influence of Sandanski, despite his assistance to the Bulgarian military during the war. Thus, Sandanski's political role came to an end in 1913. He had no choice other than to accept the new conditions. He continued to live in Macedonia and began to work as a businessman in the region. But, according to the memoirs of his friends, he was very skeptical of the Bulgarian government and disliked the Bulgarian Tsar Ferdinand ${ }^{37}$.

In the end, Sandanski's career as a revolutionary, politician, and businessman was abruptly halted when he was assassinated by Bulgarian nationalists in 1915. Many of his friends who had been with him during the Young Turks' era were assassinated by Bulgarian nationalists in the same way in the following years. Sandanski, who had been a hero among the Macedonian people already in his lifetime, became a legend after his death. He was the subject of many folksongs in Macedonia. In 1949, the socialist government in Bulgaria, in view of Sandanski as a protagonist of socialism, gave his name to a town in Macedonia ${ }^{38}$. But, as already mentioned in the introduction, this image of Sandanski in Bulgaria changed after the fall of socialist regime. 


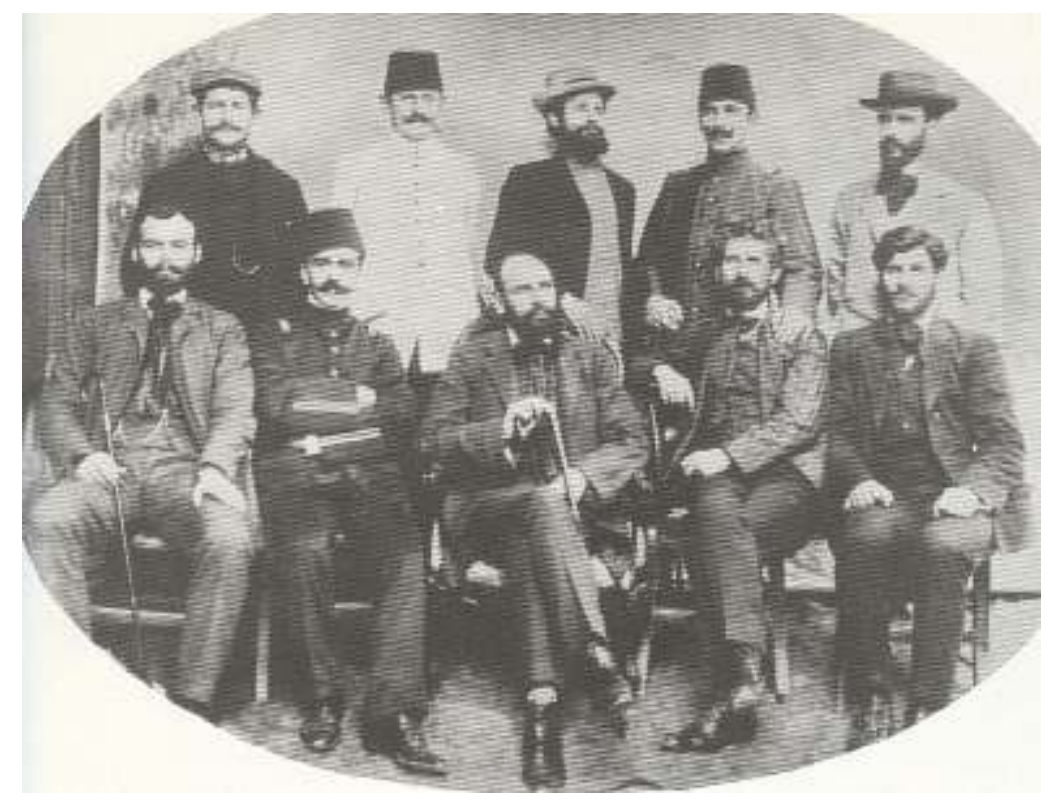

(Source : Macdermott, Za Svoboda)

\section{Evaluation of Sandanski's Role}

It is very difficult to find a definitive answer to the questions outlined in the introduction. Was Sandanski a betrayer of national Bulgarian interests in Macedonia? I suggest answering this question with a definite yes, but if we take into consideration the events in other parts of Macedonia, we can see that his region of influence with its Bulgarian-Macedonian population was not very much subjected to the oppressive measures of the CUP government. They were protected because of Sandanski's good relations with the CUP. Interestingly enough, in the end Bulgaria occupied the northern part of the region which Sandanski had dominated.

In Macedonian historiography, Sandanski has been portrayed as a fighter for Macedonian independence against the Young Turks and the Turkish rule in Macedonia. I think that this interpretation is highly problematic. He certainly stood for the autonomy of Macedonia, but this does not mean that he regarded the Slavic Christians in Macedonia as a separate nation-namely, a "Macedonian nation." On the other hand, he was not an enemy of the CUP, as he was in alliance with the Young Turks until the middle of 1912.

The final question concerns Sandanski's political ideology and aims. Did he dream of a socialist system in the Balkans? In my opinion, he supported an autonomous status for Macedonia which would allow him to maintain and expand his role as a political leader. Probably the role of ideology was only secondary in his activities. Possibly, he regarded himself as a native ruler of Macedonia, while all other Kings in the Balkan states (except for Serbia) were imported from Western Europe. 


\section{BIBLIOGRAPHY}

Adanir, Fikret, (1979), Die Makedonische Frage : Ihre Entstehung und Entwicklung bis 1908, Wiesbaden.

Adanir, Fikret, (1995), “Osmanlı İmparatorluğu'nda Ulusal Sorun ile Sosyalizmin Oluşması ve Gelişmesi : Makedonya,” in : Osmanl İmparatorluğu'nda Sosyalizm ve Milliyetçilik (1876-1923), Istanbul: eds. M. Tuncay, E. J. Zürcher, pp. 33-72.

Bilyarski, Tsočo, (1988 ), "Vătrešnata Makedono-Odrinska Revolyutsionna Organizatsiya, Săyuzăt na Bălgarskite Konstitutsionni Klubove i Narodnata Federativna Partiya (Bălgarska Sektsiya) sled Mladoturskata Revolyutsiya," in: Izvestiya na Dăržavnite Arhivi, 56 (Sofia), pp. 117-189.

Deliradev, Pavel, (1946), Yane Sandanski, Sofia.

Hacisalihoğlu, Mehmet, (2003), Die Jungtürken und die Mazedonische Frage 1899-1918, Munich.

Hacisalihoğlu, Mehmet, (2004), “The Young Turk Revolution and the Negotiations for the Solution of the Macedonian Question," in: Turcica, 36 (Paris), pp. 165-190.

MacDermott, Mercia, (1987), Za Svoboda i Săvăršenstvo : Biografiya na Yane Sandanski [For Freedom and Perfection : Biography of Yane Sandanski], transl. from English into Bulgarian by Veselin Izmirliev, Sofia.

MacDermott, (1979), Mercia, Svoboda ili Smărt : Biografiya na Gotse Delčev, Sofia.

Mičev, Nikolaï et Petur Koledarov, (1989), Rečnik na Selištata i Selištnite Imena v Bălgariya, 1878-1987, Sofia.

Minoski, Mihailo, (1985), Federativnata Ideya vo Makedonskata Politička Misla: 1887-1919, Skopje.

Mitrev, Dimitar, (1968), “Sandanski, Jane,” in: Enciklopedija Jugoslavije, Bd. 7 (Zagreb), p. 132.

Mitrev, Dimitar et al. (eds.), (1976), Yane Sandanski, 1872-1915-1975, Skopje.

Panayotopoulos, Ioannis, The "Great Idea" and the Vision of Eastern Federation: A Propos of the Views of I. Dragoumis and A. Souliotis-Nicolaïdis, in: Balkan Studies, 21, 1980, pp. 331-365.

Pandevski, Manol, (1987), Makedonskoto Osloboditelno Delo vo XIX i XX vek, vol. 4, Političkite Partii i Organizatsii vo Makedonija (1908-1912), Skopje.

Pandevski, Manol, (1983), Vnatrešnata Makedonska Revolutsionerna Organizatsija i Neovrhovizmot 1904-1908, Skopje.

Pandevski, Manol, (1981), "Yane Sandanski and the Macedonian Liberation Movement," in: Macédoine (Articles d'Histoire). Ed. A. Matkovski, Skopje, pp. 243-264.

Pandevski, Manol, (1968), Mladoturskata Revolutsija i Makedonija, Skopje.

Pandevski Manol, (1979), “Razvitokot na Političkiot Život vo Evropska Turtsija vo Periodot na Mladoturskoto Upravuvanie 1908-1912," in: Istorija, XV/2, Skopje, pp. 105-116.

Report of the International Commission to Inquire into the Causes and Conduct of the Balkan Wars, (1914), Washington, DC: The Carnegie Endowment for International Peace.

Siljanov, Hristo, (1983), Osvoboditelnite Borbi na Makedoniya, 2 vols., Sofia.

Todorova, Maria, (2008), Bones of Contention: The Living Archive of Vasil Levski and the Making of Bulgaria's National Hero, Budapest, New York.

Tokay, Gül, (1996), Makedonya Sorunu :Jön Türk İhtilalinin Kökenleri 1903-1908, Istanbul. 
Tomov, Angel, (1946), "Mestoto i Značenieto na "Odrinski Glas" v Makedonskoto Revolyutsionno Dviženie,” in: Makedonska Misăl, I/9-10, pp. 394-404.

Topalov, Kiril, (1985), Rakovski i Rigas v Kulturno-istoričeskite Modeli na Balkanskoto Văzraždane, Sofia 2003 ; Četata na Hristo Botev, Sbornik Izsledvaniya, ed., Nikolay Žečev, Sofia.

Vlahov, Tuše, (1965), "Bălgariya i Mladoturskata Revolyutsiya," in: Godišnik na Sofiyskiya Universitet Filosofski-Istoričeski Fakultet, Book 3, pp. 3-77.

Yavorov, Peio K. (1992), Gotse Delčev, Sofia; N.P. Mela, Pavlos Melas: Biographia, 1st ed. 1926, Athènes.

\section{NOTES}

1. Maria Todorova, Bones of Contention: The Living Archive of Vasil Levski and the Making of Bulgaria's National Hero, Budapest, New York 2008; Kiril Topalov, Rakovski i Rigas v Kulturno-istoričeskite Modeli na Balkanskoto Văzraždane, Sofia, 2003; Četata na Hristo Botev, Sbornik Izsledvaniya, ed., Nikolay Žečev, Sofia, 1985; P. K. Yavorov, Gotse Delčev, Sofia, 1972; N.P. Mela, Pavlos Melas: Biographia, 1st ed. 1926, Athens 1992.

2. The ancient term "Macedonia" was not used by the Ottomans for any part of the empire, but it was in use in Western Europe and in the newly established Balkan states after the beginning of the nineteenth century and particularly after the Treaty of Berlin 1878. "Macedonia" referred to the Ottoman provinces of Selanik and parts of Kosova and Manastır. Even after the Young Turk Revolution the Ottoman administration refused to use the name "Macedonia" because of its "separatist" connotations. Fikret Adanır, Die Makedonische Frage: Ihre Entstehung und Entwicklung bis 1908, Wiesbaden, 1979, p. 2.

3. Dimitar Mitrev, "Sandanski, Jane," in: Enciklopedija Jugoslavije, Bd. 7 (Zagreb 1968), p. 132.

4. For a detailed study on Sandanski in Bulgaria, see: Mercia MacDermott, Za Svoboda $i$ Săvăršenstvo: Biografiya na Yane Sandanski [For Freedom and Perfection: Biography of Yane Sandanski], transl. from English into Bulgarian by Veselin Izmirliev, Sofia, 1987. There are many other studies and memoirs dealing with Sandanski's political activities. For a very important study on the Macedonian Question, see: H. Siljanov, Osvoboditelnite Borbi na Makedoniya, 2 vols., Sofia, 1983. An important book written by a follower and companion of Sandanski is: Pavel Deliradev, Yane Sandanski, Sofia, 1946. For publications on Sandanski in the Republic of Macedonia, see: Dimitar Mitrev et al. (eds.), Yane Sandanski, 1872-1915-1975, Skopje, 1976. In Skopje, the most detailed studies on the Macedonian Question and on Sandanski were written by Manol Pandevski: M. D. Pandevski, Vnatrešnata Makedonska Revolutsionerna Organizatsija i Neovrhovizmot 1904-1908, Skopje, 1983; idem, "Yane Sandanski and the Macedonian Liberation Movement," in: Macédoine (Articles d'Histoire). Ed. A. Matkovski, Skopje, 1981, pp. 243-264. For a comprehensive study on the Macedonian Question until 1908, see: Fikret Adanır, op.cit.

5. In the Republic of Macedonia, particularly Manol Pandevski has written on Sandanski during the Young Turks' government: M. Pandevski, Makedonskoto Osloboditelno Delo vo XIX $i$ XX vek, vol. 4, Političkite Partii i Organizatsii vo Makedonija (1908-1912), Skopje, 1987; idem, Mladoturskata Revolutsija i Makedonija, Skopje, 1968; idem, "Razvitokot na Političkiot Život vo Evropska Turtsija vo Periodot na Mladoturskoto Upravuvanie 1908-1912," in: Istorija, XV/2, Skopje, 1979, pp. 105-116. In Bulgaria, for an important study on the Young Turks' era in Macedonia, see: Tuše Vlahov, "Bălgariya i Mladoturskata Revolyutsiya," in: Godišnik na Sofiyskiya Universitet Filosofski-Istoričeski Fakultet, 1965, Book 3, pp. 3-77. For an evaluation of these studies and a detailed discussion of the Young Turks' rule in Macedonia, see: Mehmet Hacısalihoğlu, Die Jungtürken und die Mazedonische Frage 1899-1918, Munich, 2003. 
6. See particularly: Stoyan Boyadžiev, Istinskiyat Lik na Yane Sandanski, Sofia, [1997].

7. Pandevski, Političkite Partii i Organizatsii, pp. 387-419.

8. Manol Pandevski et al. (eds.), Gotse Delčev: Prilozi za Likot $i$ Revolutsionernata Dejnost, Štip, 1986.

9. Mercia MacDermott, Svoboda ili Smărt: Biografiya na Gotse Delčev, Sofia, 1979.

10. For federation concepts among the Bulgarians-Macedonians and Greeks, see: M. Minoski, Federativnata Ideya vo Makedonskata Politička Misla: 1887-1919, Skopje, 1985; A. J. Panayotopoulos, The "Great Idea" and the Vision of Eastern Federation: A Propos of the Views of I. Dragoumis and A. Souliotis-Nicolaïdis, in: Balkan Studies, 21, 1980, pp. 331-365.

11. F. Adanır, Die Makedonische Frage, p. 245; Gül Tokay, Makedonya Sorunu: Jön Türk İhtilalinin Kökenleri 1903-1908, Istanbul, 1996, pp. 141-142.

12. H. Silyanov, Osvoboditelnite Borbi na Makedoniya, vol. 2, pp. 511; Angel Tomov, "Mestoto i Značenieto na "Odrinski Glas" v Makedonskoto Revolyutsionno Dviženie," in: Makedonska Misăl, I/ 9-10 (1946), pp. 394-404.

13. In 1950, the name of the city was changed by the socialist government in Bulgaria to Gotse Delčev. N. Mičev, P. Koledarov, Rečnik na Selištata i Selištnite Imena v Bălgariya, 1878-1987, Sofia, 1989, p. 84.

14. M. Hacısalihoğlu, Die Jungtürken, pp. 115-125.

15. M. MacDermott, Za Svoboda, pp. 296-300.

16. “Sandanski," Yeni Astr, No. 1304, 16 Temmuz 1324 / 29 Juillet 1908, p. 2.

17. Yeni Astr, No. 1305, 17 Temmuz 1324 / 30 Juillet 1908, p. 2.

18. "Mukaddes vatan benden ne gibi hıdmet ümid eder, beni hangi işe memur ederse, vazifemi ifaya dağlarda çalıșdığım gibi can ve baş ile uğraşacağım.” Yeni Asır, No. 1306, 18 Temmuz 1324 / 31 Juillet 1908, p. 1.

19. Original leaflet: Manifest kăm Vsičkite Narodnosti v Imperiyata, 18 July (old style) 1908, in: Tsentralen Dăržaven Istoričeski Arhiv (Sofia), Fond 771, Op. 2, a.e. 17.

20. M. Hacısalihoğlu, Die Jungtürken, pp. 222-223.

21. M. Hacısalihoğlu, Die Jungtürken,p. 221.

22. "Programme de l'Organisation Révolutionnaire Macédono-Adrinopolitaine. (Projet élaboré par les départements révolutionnaires de Stroumitza, Salonique et Serrès," in: Konstitutsionna Zarya, 1 (Middle of August 1908), p. 2.

23. "Déclaration," 8/21 August 1908, in: Konstitutsionna Zarya, 1 (Middle of August 1908), p. 2.

24. For the program of the CUP, see: Tsočo Bilyarski, "Vătrešnata Makedono-Odrinska Revolyutsionna Organizatsiya, Săyuzăt na Bălgarskite Konstitutsionni Klubove i Narodnata Federativna Partiya (Bălgarska Sektsiya) sled Mladoturskata Revolyutsiya," in: Izvestiya na Dăržavnite Arhivi, 56 (Sofia 1988), pp. 117-189, here 135-136.

25. Mehmet Hacısalihoğlu, "The Young Turk Revolution and the Negotiations for the Solution of the Macedonian Question," in: Turcica, 36 (Paris 2004), pp. 165-190.

26. M. Hacısalihoğlu, Die Jungtürken, pp. 250-253.

27. The new newspaper was to replace the former newspapers of the left wing, Konstitutsionna Zarya and Edinsvo, Narodna Volya, Organ na Bălgarskata Narodna Federativna Partiya, No. 1, January 17, 1909.

28. M. MacDermott, Za Svoboda, pp. 346, 357, 370-371.

29. “Cem'iyetler kānūnu," 3 Ağustos 1325, in: Düstūr, Seriel II, Vol. I: 1326-1327 [1908-1909]. Dersa'ādet 1329.

[Istanbul 1911], pp. 604-608. Entry into force: 10 August 1325 / 23 August 1909, published in the official newspaper Takvim-i Vekayi.

30. M. Hacısalihoğlu, Die Jungtürken, pp. 289-292.

31. M. MacDermott, Za Svoboda, pp. 374-375. In Drama, too, the mutasarrif (governor) Tahsin Bey [Uzer] asked Sandanski's friend Panitsa to decommission all weapons. Panitsa declared that in his region there were no illegal activities and refused to give up any weapons. Tahsin Bey accepted 
this statement and did not disarm the population in that region. See the memoirs of $\mathrm{Y}$. Boyadžiev, a revolutionary within the group of Sandanski, in: Tsentralen Dăržaven Istoričeski Arhiv (Sofia), Fond 526, Op. 1, a.e. 1210, f. 1-2.

32. For the attitude of the Bulgarian socialists towards the CUP government, see: F. Adanir, "Osmanlı İmparatorluğu'nda Ulusal Sorun ile Sosyalizmin Oluşması ve Gelişmesi: Makedonya," in: Osmanlı İmparatorluğu'nda Sosyalizm ve Milliyetçilik (1876-1923), eds. M. Tuncay, E. J. Zürcher, Istanbul 1995, pp. 33-72.

33. The deputy Pančo Dorev, who was elected in 1908 with the support of the Bulgarian Exarchate, gradually changed his attitude towards the policy of the Bulgarian Constitution Clubs and in 1911 and 1912 openly rejected the Bulgarian nationalist policy in Macedonia. In the general elections of 1912, he made an alliance with the CUP. Consequently, he was re-elected in Skopje. His friends Yordan Nikolov (Salonica) and Todor Paskalev (Bitola) were also elected. M. Hacısalihoğlu, Die Jungtürken, pp. 315-322, 366.

34. M. MacDermott, Za Svoboda, pp. 382-392; M. Hacısalihoğlu, Die Jungtürken, pp. 370-372.

35. The Carnegie Endowment for International Peace, Report of the International Commission to Inquire into the Causes and Conduct of the Balkan Wars, Washington, DC. 1914, p. 279.

36. M. MacDermott, Za Svoboda, pp. 384-385.

37. P. Deliradev, Yane Sandanski, p. 42.

38. The town Sveti Vrač within the district of Melnik was changed to Sandanski, Minčev / Koledarov, op.cit., p. 237.

\section{ABSTRACTS}

Yane Sandanski has been a hero among the Macedonian population in his lifetime, and after his death a legend in the region and the subject of many folksongs in the region. However his image is today very controversial in national historiographies in the Balkan states. Revolutionary, politician and businessman in the end, he was killed by the Bulgarian nationalists in 1915. Now it is difficult to give an absolute evaluation of his role and his political aims. Was he a betrayer of the national Bulgarian interests in Macedonia? definitely yes! But his alliance with the CUP protected his region from any oppression from this part. He was sure for an autonomy of Macedonia, but this does not mean that he regarded the Slavic Christians in Macedonia as a separate nation, namely a "Macedonian nation".

Yane Sandanski a été de son vivant un héros dans la population macédonienne, et après sa mort, une légende dans toute la région et le sujet de nombreux chants populaires dans la région. Cependant, son image est aujourd'hui très controversée dans les historiographies des États balkaniques. Révolutionnaire, politicien et hommes d'affaires, il a été tué par les nationalistes bulgares en 1915. Il est difficile maintenant de formuler un jugement définitif sur son rôle et ses buts politiques. A-t-il trahi les intérêts nationaux bulgares en Macédoine? Sans aucun doute! Mais son alliance avec le CUP a protégé sa région de toute oppression de ce côté. Il était assurément pour une autonomie de la Macédoine, mais cela ne signifie pas qu'il considérait les chrétiens slaves de la région comme une nation distincte, une « nation macédonienne ».

Yane Sandanski henüz hayattayken Makedonya halkı arasında kahraman olmuş Makedonyalı bir ihtilalci idi ve ölümünden sonra bölgede bir çok halk türküsüne konu olan bir efsane haline geldi. 
Bununla birlikte Sandanski günümüzde Balkan ülkelerinin tarih yazımlarında çelişkili bir imaja sahiptir. Önce ihtilalci, sonra politikacı ve daha sonra da işadamı olan Sandanski 1915 yılında Bulgar milliyetçileri tarafından öldürüldü. Sandanski'nin rolü ve siyasi amaçları hakkında kesin bir değerlendirme yapmak günümüzde oldukça zordur. Makedonya'daki Bulgar milliyetçi hedeflerinin düşmanı mıydı? Kesinlikle evet ! Fakat onun İttihad ve Terakki Cemiyeti ile ittifakı, etkisi altında bulunan bölgeyi hükümetin her türlü baskısından korudu. şüphesiz Makedonya'nın özerkliğini savunuyordu, fakat bu Sandanski'nin Makedonya'daki Slav Hıristiyanları ayrı bir ulus, yani bir "Makedonya ulusu" olarak gördüğü anlamına gelmez.

\section{INDEX}

Geographical index: Macédoine, Drama, Istanbul, Monastir, Nevrokop, Salonique motsclesmk ИСТАНБУЛ, МАКЕДОНИЈА, НЕВРОКОП, СОЛУН, БИТОЛА

Mots-clés: Sandanski Yane (1872-1915), CUP, Exarchat, Delčev Gotse (1872-1903), Fédaï, IMRO/

VRMO, Pavlos Mélas (1870-1904), Sandanski Yané (1872-1915), San Stefano

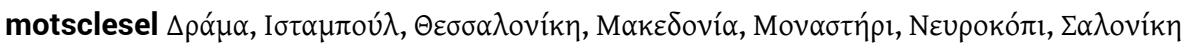

Keywords: Sandanski Yane (1872-1915), Macedonia, Salonika, Drama, Istanbul, Monastir, Nevrokop, Young Turks revolution (1908-1914), History

motsclestr Drama, İstanbul, Selanik, Makedonya, Monastir, Nevrokop, Bitola

Chronological index: révolution jeune-turque (1908-1914) 